\title{
RECURRENT PAROTITIS IN CHILDREN
}

\author{
BY \\ H. EVERLEY JONES \\ From the Roval Hospital, Wolverhampton
}

(RECEIVED FOR PUblication february 16, 1953)

From time to time a child is seen with swelling of the parotid gland in whom mumps is diagnosed, yet the parent states that the patient has had that disease several times before. Due largely to the work of Payne (1933, 1938, 1940) the condition of recurrent parotid swelling has been defined as a clinical entity, but most of the published accounts refer to adults. The disease, however, is by no means rare in children, as can be seen from the fact that 17 examples have been seen in one part of the Midlands in the past five years. The salient features of these patients are recorded in the table.

The essential feature of the condition is swelling of one or both parotid salivary glands. This recurs once or many times (Fig.

1). Sometimes the swelling is confined to one side, but recurrences need not always affect the same side and both sides may be involved on each occasion; or a unilateral case may become bilateral or vice versa. In the examples recorded here the whole parotid gland has been enlarged and there was usually tender-

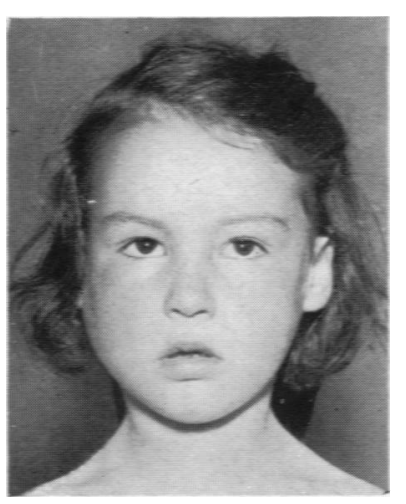

Fig. 1.-Right-sided parotitis. ness, but there has been no redness or oedema of the overlying skin.

In frequently recurring cases not only does the enlargement tend to be greater than in those which relapse rarely, but enlargement of varying degree may persist between periods of activity.

Pain has been a variable feature: probably some discomfort is always experienced and this may rarely be severe. Usually the sufferers complain of moderate discomfort for the duration of the swelling, which has lasted from a few minutes, especially after treatment, to several weeks.
The onset has usually been abrupt and has in less than a quarter of the patients coincided with the taking of food, although one boy, before he was treated, could always provoke an attack by taking vinegar. The frequency of attacks has varied from about one a year to one a week.

The orifice of Stenson's duct has not appeared abnormal, though Bigler (1946) has described redness and oedema, but no thickening of the duct has been felt.

When the disease was active mucopurulent saliva could nearly always be expressed from the affected gland. In the majority only a small quantity was obtained, but in those children from whose saliva the pneumococcus was isolated a larger amount appeared and in two on several occasions purulent discharge was seen to drip from the orifice of the parotid duct. In most of the patients the secretion presented the 'snowstorm' effect described by Payne (1938), the fiakes being small masses of mucus and cells suspended in mucopurulent saliva. After treatment the 'snowstorm' appearance was infrequently seen and between periods of activity little or no discharge could be expressed.

Fever and leucocytosis have been inconstant features. The temperature was often normal at the height of the swelling. The maximum white cell count has been 24,800 per c.mm. with $78 \%$ polymorphonuclear cells in a case from which both the haemolytic streptococci and pneumococci were isolated. As a rule the white count has been from 8 to 10,000 leucocytes per c.mm. The usually more severe pneumococcal cases have tended to be associated with the most marked leucocytosis.

The diagnosis is confirmed by sialography, which showed characteristic changes in 13 of the 14 cases in which it was done. This is in contrast to the findings of Bigler (1946) who recorded normal radiographs in the few cases of his series in which this examination was performed.

In each case a plain film was taken to exclude the presence of a calculus which was never found. Next, following the technique of Payne (1931) and 
Ollerenshaw and Rose (1951) 1-2 ml. of 'neohydriol fluid" was injected with a syringe and small blunted hypodermic needle into Stenson's duct and lateral and postero-anterior projections were made. In the normal gland the ducts were well outlined and it

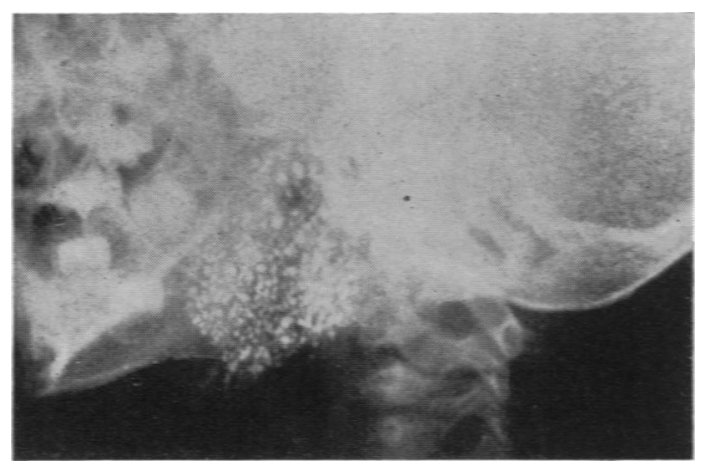

Frg. 2.-Sialogram showing mild sialectasis.

proved impossible to avoid some filling of the acini. This acinar filling, called by Samuel (1950) 'sialoacinar reflux', has been shown by Ollerenshaw and Rose (1951) to be the normal result of proper filling with the opaque medium. In 10 patients of this series a spherical dilatation of the finer ducts was seen: in one case infected with the pneumococcus, a gross type of change, described by Payne (1933) as destructive, was seen, and in two of the remaining three the dilatation was intermediate between the two types (Figs. 2, 3 and 4). In one only was the sialogram normal. In addition, the main ducts in four children showed some dilatation with a tendency to beading.

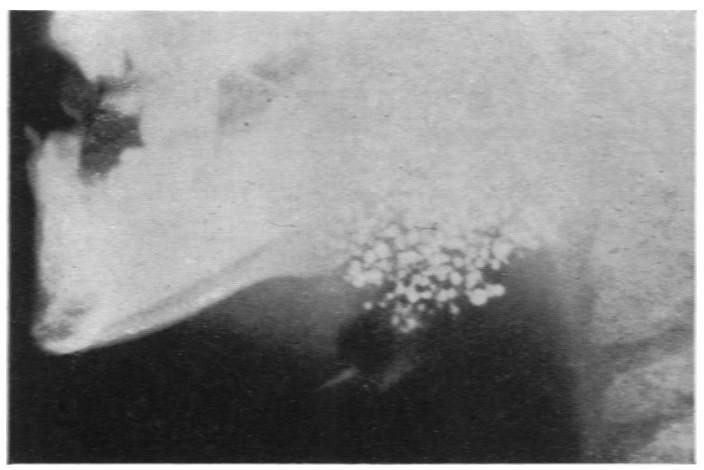

FiG. 3.-Sialogram showing moderate sialectasis.

An interesting feature was the persistence of small quantities of opaque medium in the glands of three patients in whom radiography was repeated after intervals of six months, 13 months and two years after the first examination.

\section{Bacteriology}

Three types of purulent parotitis are described by Payne (1940): first that due to Staphylococcus aureus which gives rise to acute parotitis; secondly that caused by the $x$-haemolytic streptococcus which results in recurrent parotitis; and thirdly that from which the pneumococcus has been isolated, a recurrent parotitis of a more severe type which may proceed to abscess formation. Acute parotitis is not included in this paper, as no example of this condition has been seen which went on to the recurrent form of the disease.

The majority of the cases in this series, all but five, fall into the second group and the $x$-haemolytic streptococcus was isolated from the parotid saliva in each of these. In the remaining five pneumococci in pure culture were isolated in two and both pneumococci and $x$-haemolytic streptococci were obtained from the other three. Three of the latter

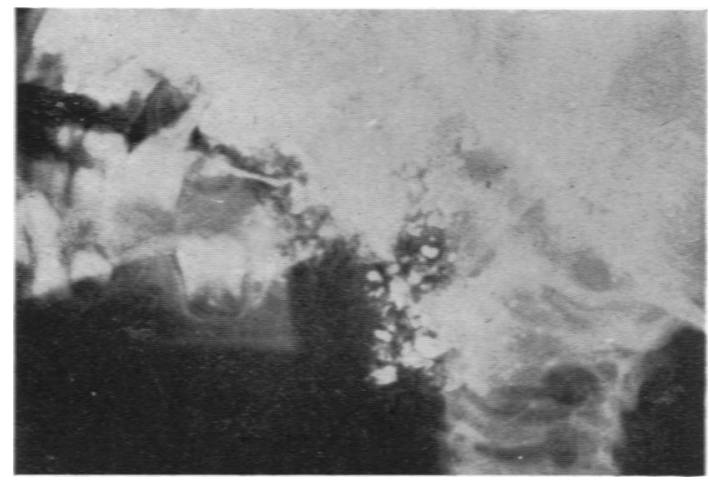

Fig. 4.-Sialogram showing severe sialectasis.

five were the most severe examples in the series and one child had severe pain and constant swelling of both parotids. Unfortunately full investigation and treatment were refused and he could not be traced. Yet not all cases associated with the pneumococcus are necessarily severe, as the only normal sialogram seen was that of a boy from whose parotid secretion pneumococci and $x$-haemolytic streptococci were isolated.

\section{Treatment}

Effective treatment can hardly be expected without an understanding of the cause of the condition. Possible factors concerned in the aetiology are discussed below, but it would seem most important to eliminate septic foci in the mouth, particularly carious teeth and infected tonsils, and this was done when considered necessary. It is perhaps significant that the only normal sialogram was obtained from a patient in whom no evidence of infection was found. 
IAELE

SALIENT FEATURES OF 17 CASES OF PAROTITIS

\begin{tabular}{|c|c|c|c|c|c|c|c|c|c|c|c|c|}
\hline Name & Sex & 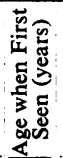 & $\begin{array}{l}\text { Age at } \\
\text { Onset } \\
\text { (years) }\end{array}$ & 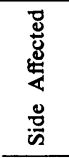 & $\begin{array}{l}\text { Frequency } \\
\text { of Attacks }\end{array}$ & $\begin{array}{c}\text { Duration } \\
\text { of Attacks }\end{array}$ & Symptoms & Organism & Sialogram & Septic Foci & Treatment & 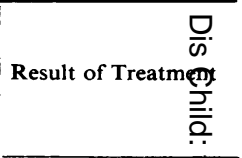 \\
\hline D.A. & $\mathbf{M}$ & 11 & 9 & $\mathbf{R}$ & 2 a year & 2 weeks & $\begin{array}{l}\text { Marked } \\
\text { pain. Un- } \\
\text { able to } \\
\text { chew }\end{array}$ & $\underset{\text { streptococcus }}{\alpha \text { Haemolytic }}$ & $\begin{array}{l}\text { Mild } \\
\text { sialectasis }\end{array}$ & $\begin{array}{l}\text { Otitis media, } \\
\text { tonsillectomy } \\
\text { (5) turbinec- } \\
\text { tomy }(8) \text {, den- } \\
\text { tal cariest }\end{array}$ & $\begin{array}{l}\text { One } \\
\text { course } \\
\text { penicillin }\end{array}$ & 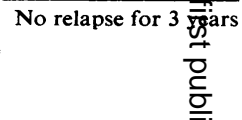 \\
\hline B.D. & $\mathbf{M}$ & 10 & $9 \frac{1}{2}$ & $\underset{\mathbf{L}}{\mathbf{R}}>$ & $\begin{array}{l}5 \text { in } 6 \\
\text { months }\end{array}$ & 3 days & $\begin{array}{l}\text { Marked } \\
\text { pain, un- } \\
\text { able to } \\
\text { chew, } \\
\text { vinegar } \\
\text { provokes }\end{array}$ & $\underset{\text { streptococcus }}{\alpha \text { Haemolytic }}$ & $\begin{array}{l}\text { Mild } \\
\text { sialectasis }\end{array}$ & $\begin{array}{l}\text { Recurrent } \\
\text { aphthous } \\
\text { stomatitis, } \\
\text { recurrent } \\
\text { tonsillitis }\end{array}$ & $\begin{array}{l}\text { One } \\
\text { course } \\
\text { penicillin }\end{array}$ & 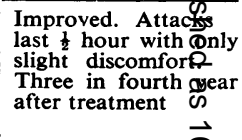 \\
\hline K.J. & $\mathbf{F}$ & 3 & $2 \frac{1}{2}$ & $\mathbf{R}$ & $\begin{array}{l}3 \text { in } 6 \\
\text { months }\end{array}$ & $\begin{array}{l}\text { Up to } 4 \\
\text { weeks }\end{array}$ & Painful & $\underset{\text { streptococcus }}{\alpha \text { Haemolytic }}$ & $\begin{array}{l}\text { Mild } \\
\text { sialectasis }\end{array}$ & $\begin{array}{l}\text { Dental caries, } \\
\text { otitis media }\end{array}$ & $\begin{array}{l}\text { One } \\
\text { course } \\
\text { penicillin }\end{array}$ & $\begin{array}{l}\text { Greatly improved } \\
\text { One } \frac{1}{2} \text { hour attael in } \\
4 \text { years }\end{array}$ \\
\hline S.S. & $\mathbf{M}$ & 11 & Unknow * & $\mathbf{R}$ & Frequent & $\begin{array}{l}\text { Several } \\
\text { days }\end{array}$ & Slight pain & $\begin{array}{c}\alpha \text { Haemolytic } \\
\text { streptococcus }\end{array}$ & $\begin{array}{l}\text { Mild } \\
\text { sialectasis }\end{array}$ & $\begin{array}{l}\text { Ectodermal } \\
\text { dysplasia, } \\
\text { recurrent } \\
\text { tonsillitis }\end{array}$ & $\begin{array}{l}\text { One } \\
\text { course } \\
\text { penicillin }\end{array}$ & $\begin{array}{l}\text { Greatly improved } \\
\text { Three attacks } 1 \\
\text { day each in } 3 \text { years }\end{array}$ \\
\hline C.S. & $\mathbf{M}$ & 13 & Unknown* & $\mathbf{R}$ & Frequent & $\begin{array}{l}\text { Several } \\
\text { days }\end{array}$ & Slight pain & $\underset{\text { streptococcus }}{\alpha \text { Haemolytic }}$ & Not done & $\begin{array}{l}\text { Ectodermal } \\
\text { dysplasia, } \\
\text { recurrent } \\
\text { tonsillitis }\end{array}$ & $\begin{array}{l}\text { Massage } \\
\text { only }\end{array}$ & $\begin{array}{l}\text { Improved. Attacks } \\
\text { fewer and last uff to } \\
3 \text { days }\end{array}$ \\
\hline D.M. & $\mathbf{M}$ & 5 & 4 & $\mathbf{R}$ & 4 a year & 1-3 days & $\begin{array}{l}\text { Slight } \\
\text { discomfort }\end{array}$ & $\underset{\text { streptococcus }}{\alpha \text { Haemolytic }}$ & $\begin{array}{l}\text { Unsuc- } \\
\text { cessful }\end{array}$ & Dental caries & $\begin{array}{l}\text { Massage } \\
\text { and one } \\
\text { course } \\
\text { parenteral } \\
\text { penicillin }\end{array}$ & $\begin{array}{ll}\text { No attack in } 6 & \mathrm{~N} \\
\text { months } & \text { 음 } \\
& \end{array}$ \\
\hline E.F. & $\mathbf{M}$ & 13 & 3 & $\begin{array}{l}\mathbf{R} \\
\mathbf{L}\end{array}$ \& & $\begin{array}{l}2-3 \text { a } \\
\text { year }\end{array}$ & 2 weeks & $\begin{array}{l}\text { Slight } \\
\text { discomfort }\end{array}$ & $\begin{array}{l}\alpha \text { Haemolytic } \\
\text { streptococcus } \\
\text { Pneumococcus }\end{array}$ & Normal & None & $\begin{array}{l}\text { One } \\
\text { course } \\
\text { penicillin, } \\
\text { one } \\
\text { course } \\
\text { strepto- } \\
\text { mycin }\end{array}$ & $\begin{array}{l}\text { Slight improvem } \\
\text { after first course. } \\
\text { Then organisms be- } \\
\text { came penicillin fefis- } \\
\text { tant. After sefofids } \\
\text { course attack lasted } \\
\text { 1-2 days. Inedenge } \\
\text { unchanged }\end{array}$ \\
\hline T.L. & $\mathbf{M}$ & 5 & 5 & $\begin{array}{l}\mathbf{L}> \\
\mathbf{R}\end{array}$ & $\begin{array}{l}2 \text { in a } \\
\text { month }\end{array}$ & 3 days & $\begin{array}{l}\text { Slight } \\
\text { discomfort }\end{array}$ & $\underset{\text { streptococcus }}{\alpha \text { Haemolytic }}$ & $\begin{array}{l}\text { Mild } \\
\text { sialectasis }\end{array}$ & $\begin{array}{l}\text { Otitis media, } \\
\text { recurrent } \\
\text { tonsillitis }\end{array}$ & $\begin{array}{l}\text { Massage } \\
\text { only }\end{array}$ & $\begin{array}{l}\text { Much improved. } \\
\text { attack in } 3 \text { years }\end{array}$ \\
\hline O.M. & $\mathbf{F}$ & $4 \frac{1}{2}$ & $2 \frac{1}{2}$ & $\underset{\mathbf{R}}{\mathbf{L}>}$ & $\begin{array}{l}1 \text { a } \\
\text { month }\end{array}$ & $\begin{array}{l}\text { Up to } 7 \\
\text { days }\end{array}$ & $\begin{array}{l}\text { Marked } \\
\text { pain, } \\
\text { drinks only } \\
\text { cold fluids }\end{array}$ & $\begin{array}{l}\alpha \text { Haemolytic } \\
\text { streptococcus } \\
\text { Pneumococcus }\end{array}$ & $\begin{array}{l}\text { Moderate } \\
\text { sialectasis }\end{array}$ & $\begin{array}{l}\text { Dental caries, } \\
\text { recurrent } \\
\text { tonsillitis }\end{array}$ & $\begin{array}{l}\text { Two } \\
\text { courses } \\
\text { penicillin }\end{array}$ & $\begin{array}{l}\text { Much improved. } \\
\text { mild attacks in } \\
\text { months after se } 18 \text { है। } \\
\text { course }\end{array}$ \\
\hline B.K. & $\mathbf{M}$ & 9 & 7 & $\mathbf{R}$ & 6 a year & 1-7 days & Painful & $\underset{\text { streptococcus }}{\alpha \text { Haemolytic }}$ & $\begin{array}{l}\text { Mild } \\
\text { sialectasis }\end{array}$ & $\begin{array}{l}\text { Recurrent } \\
\text { tonsillitis, } \\
\text { tonsillectomy } \\
\text { \& antrostomy } \\
\text { (9) }\end{array}$ & $\begin{array}{l}\text { One } \\
\text { course } \\
\text { penicillin }\end{array}$ & No relapse for 3 years \\
\hline J.F. & $\mathbf{F}$ & 2 & $1_{12}^{4}$ & $\underset{\mathbf{R}}{\mathbf{L}}>$ & $\begin{array}{l}1 \text { a } \\
\text { month }\end{array}$ & $\begin{array}{l}\text { Up to } 7 \\
\text { days }\end{array}$ & $\begin{array}{l}\text { Slight } \\
\text { discomfort }\end{array}$ & $\underset{\text { streptococcus }}{\alpha \text { Haemolytic }}$ & $\begin{array}{l}\text { Mild } \\
\text { sialectasis }\end{array}$ & $\begin{array}{l}\text { Dental caries, } \\
\text { tonsillitis }\end{array}$ & $\begin{array}{l}\text { One } \\
\text { course } \\
\text { penicillin }\end{array}$ & $\begin{array}{l}\text { Greatly improved. } \\
\text { One mild attack in } 4 \\
\text { years }\end{array}$ \\
\hline J.T. & $\mathbf{F}$ & 4 & $3 \frac{8}{4}$ & $\underset{\mathbf{L}}{\mathbf{R}} \&$ & $\begin{array}{l}2 \text { in } 3 \\
\text { months }\end{array}$ & 6 weeks & $\begin{array}{l}\text { Slight pain, } \\
\text { siallorrhoea }\end{array}$ & Pneumococcus & $\begin{array}{l}\text { Marked } \\
\text { sialectasis }\end{array}$ & $\begin{array}{l}\text { Otitis media, } \\
\text { tonsillitis, } \\
\text { tonsillectomy } \\
\text { (5) }\end{array}$ & $\begin{array}{l}\text { Two } \\
\text { courses } \\
\text { penicillin }\end{array}$ & $\begin{array}{l}\text { Slight improvement } \\
\text { after first course. 影o } \\
\text { attacks in } 18 \text { months } \\
\text { after second couge }\end{array}$ \\
\hline R.F. & $\mathbf{M}$ & 11 & 6 & $\begin{array}{l}\mathbf{R} \\
\mathbf{L}\end{array}$ & $\begin{array}{l}\text { Almost } \\
\text { continu- } \\
\text { ous }\end{array}$ & - & $\begin{array}{l}\text { Severe pain, } \\
\text { constitu- } \\
\text { tional upset }\end{array}$ & Pneumozoccus & Not done & Dental caries & None & Not traced \\
\hline M.H. & $\mathbf{F}$ & $3 \frac{1}{2}$ & $1 \frac{1}{2}$ & $\mathbf{R}$ & 1 a year & 3 weeks & Slight pain & $\underset{\text { streptococcus }}{\alpha \text { Haemolytic }}$ & $\begin{array}{l}\text { Moderate } \\
\text { sialectasis }\end{array}$ & Dental caries & $\begin{array}{l}\text { One } \\
\text { course } \\
\text { penicillin }\end{array}$ & $\begin{array}{l}\text { One attack lasting } 6 \\
\text { days in } 7 \text { months }\end{array}$ \\
\hline A.H. & $\mathbf{F}$ & 8 & 7 & $\underset{\mathbf{L}}{\mathbf{R}} \boldsymbol{\&}$ & 2 a year & 3 days & $\begin{array}{l}\text { Slight } \\
\text { discomfort }\end{array}$ & $\underset{\text { streptococcus }}{\alpha \text { Haemolytic }}$ & $\begin{array}{l}\text { Mild } \\
\text { sialectasis }\end{array}$ & Dental caries & $\begin{array}{l}\text { One } \\
\text { course } \\
\text { penicillin }\end{array}$ & One attack in 3 yors \\
\hline L.T. & $\mathbf{M}$ & 11 & $2 \frac{1}{2}$ & $\mathbf{L}$ & 4 a year & 2-14 days & Painful & $\underset{\text { streptococcus }}{\alpha \text { Haemolytic }}$ & $\begin{array}{l}\text { Mild } \\
\text { sialectasis }\end{array}$ & $\begin{array}{l}\text { Recurrent } \\
\text { tonsillitis, } \\
\text { tonsillectomy } \\
(8)\end{array}$ & $\begin{array}{l}\text { One } \\
\text { course } \\
\text { penicillin }\end{array}$ & No attack in $3 \frac{1}{2}$ yeq \\
\hline
\end{tabular}

* Orphan brothers from whom no accurate history could be obtained. †Numbers in brackets indicate age at which operation was performed. 
The dilatation of the finer ducts seen in the sialograms suggests that stagnation of secretion favours the development of infection. Clearly such stagnation should be prevented, and this is best done by massage, a method strongly advocated by Payne (1933). The patients, or their mothers in the case of the youngest, were instructed to massage the cheek overlying the gland from the periphery of that structure towards the duct orifice. The effect of this simple procedure was difficult to assess but it was undoubtedly useful and sometimes seemed to abort attacks.

In 1948 an attempt was made to attack the infecting organisms directly by injecting penicillin into Stenson's duct. This method was used independently by Rose (1950) with 'uniformly satisfactory results', but no details were given in his article. Penicillin, 100,000 units per ml., was injected slowly into the orifice of Stenson's duct by means of a syringe and blunt-pointed needle. Usually $1 \mathrm{ml}$. was slowly injected into the gland and no anaesthetic was found necessary even in quite small children, for with gentleness the injection appeared to cause little discomfort. The treatment was repeated daily for about six days, and in some cases a second course was given after an interval of some months. On one occasion streptomycin was substituted for penicillin as the infective organism had become resistant to penicillin. The results achieved by this treatment have been encouraging but many patients must be followed well into adult life before its true worth becomes apparent. Some improvement, over and above that caused by simple massage, always followed and in some instances the results were striking; three patients have had no relapse for over three years after one course of injections and three others have experienced but one attack in the same period (four years in two cases). Improvement generally took the form of a reduction in the duration of the periods of activity and most of the children stated that their relapses lasted for a much shorter period and caused less discomfort.

It is probably true that dilatation of the parotid duct per se is a valuable element in treatment, making drainage assisted by massage easier. The preliminary sialogram often caused an unexpectedly long period of freedom from activity (three years in one child) yet the persistence of opaque material in the gland for periods up to two years shows that massage does not always result in complete drainage.

Parenteral injection of penicillin, 100,000 units every six hours for five days, has not proved effective in stopping relapses, though Debré and Loewe-Lyon (1951), in a girl of 8 years, found that large doses of penicillin given parenterally cut short the relapses.
In this case 150,000 units a day proved ineffective while 800,000 units or more daily were successful.

A further difficulty in assessing the results of treatment is shown by two of the children's mothers who both had the disease in girlhood and in whom spontaneous cure took place.

\section{Discussion}

Why should the parotid gland alone of the salivary glands be affected by this disease? Consideration of the structure of the glands may supply an answer. All three pairs of salivary glands are formed of lobules consisting of acini drained by small ducts. The structure of these acini varies according to whether they secrete mucus or serous material. Submaxillary and sublingual salivary glands are 'mixed' and contain both mucous and serous acini but the parotids are purely serous. Mucous acini are comparatively large and joined to the ducts by wide channels, while serous acini are smaller and have longer and narrower connecting channels, an arrangement which favours stagnation of secretion (Sharpey-Schafer, 1949). Moreover, Stenson's duct is about 2 inches long, with a diameter of $\frac{1}{8}$ inch, though the terminal opening is even narrower and the duct is angled as it traverses the buccinator muscle. Similarity to bronchiectasis developing in a portion of lung collapsed as a result of obstruction of the segmental bronchus is apparent and the importance of adequate drainage seen. In fact immediate improvement has been seen when a free flow of parotid saliva has been effected. If, as seems likely, infection ascends up the duct from the mouth, the importance of any buccal focus of infection is clear and in the majority of patients dental infection, septic tonsils or obstruction of the nasal airway has been noted. This assumption is suggested by the findings of Berndt, Buck and Buxton (1931) who injected the parotid ducts of 15 dogs with a suspension of Staphylococcus aureus and produced parotitis in 10 of them, while similar injection into the artery of the parotid caused parotitis in only three of 15 animals. A further point is that if anything should interfere with adequate chewing stagnation of saliva in Stenson's duct may occur, and Payne (1940) remarks that many patients date the origin of their symptoms to the time of the first or second dentitions. He also points out that mucus is bactericidal and that the parotid is primarily a serous gland. In this connexion two of the present group of patients are interesting. These two are orphan brothers and both suffer from congenital ectodermal dysplasia. Their mouths are rather dry and presumably scanty parotid secretion favours stagnation and resulting ascending infection. 
Bruce Pearson (1935) described 11 cases, seven under 12 years of age, of recurring parotid swelling characterized by a lack of evidence of infection and commonly a history of allergy. During an attack of swelling in one of these cases plugs containing eosinophils were obtained from Stenson's duct. He postulated that the condition resulted either from obstruction to Stenson's duct by spasm or oedema or else to achalasia of the duct. In three of the present series there was a family history of allergy; in one the mother was asthmatic, in the second an aunt had hay fever and in the third an aunt suffered from asthma. Two of the children's mothers had suffered from a similar disease, in one case until the age of 14 and in the other from 8 to 11 years of age, although in neither of these families was any form of allergy detected. One boy had paroxysmal rhinorrhoea with an eosinophil count of $8 \%$ without any allergic family history, but he was the only patient in whom any form of allergy was detected. In no case were cosinophil cells found in the parotid secretion. In view of the frequency of allergy in one form or another in the general population there seems insufficient evidence that it played a causative role in these 17 patients.

Differential Diagnosis. The commonest initial diagnoses made in these children were either mumps or cervical adenitis. The latter is soon refuted by careful examination. One attack of mumps is generally regarded as conferring a permanent immunity and a history of contact has not been obtained in a single case. In mumps the typical mucopurulent secretion cannot be obtained from Stenson's duct. Applebaum (1944) has shown that the serum amylase is raised above the normal value of up to 150 units in $95 \%$ of mumps cases during the active phase of the disease and in three of this series a normal value was obtained at the height of the parotid swelling.
Neoplasms, leukaemia, sarcoidosis and salivary calculus are rare courses of parotid enlargement in children and are normally readily excluded.

\section{Summary}

Seventeen cases of recurrent swelling of the parotid gland are described.

The condition is thought to be due to infection originating in the mouth or post-nasal space ascending to the parotid duct, associated with stagnation of the secretion in the gland.

A method of treatment is described, which commonly cut short the period of activity of the disease and sometimes caused complete relief.

I wish to thank Dr. A. P. Booth for his help with the radiographs and Mr. D. R. Paton for the photographs.

\section{Referevces}

Applebaum, I. L. (1944). Ann. intern. Med., 21, 35.

Berndt, A. L., Buck, R. and Buxton, R. von L. (193i). Amer. J. med. Sci., 182,639

Bigler, J. A. (1946). Med. Clin. N. Amer., 30, 97

Debré, R. and Loewe-Lyon, S. (1951). Arch. franc. pediat., 8, 581

Payne, R. T. (1931). Brit. J. Surg., 19, 142.

(1933). Lancet, 1, 348.

(1938). Proc. roy. Soc. Med., 31, 398.

(1940). Brit. med. J., i, 287.

Olkerenshaw, R. G. W. and Rose, S. S. (1951). Brit. J. Radiol., 24. 538. Pearson, R. S. B. (1935). Archives of Disease in Childhood, 10, 363.

Rose, S. S. (1950). Postgrad. med. J., 26, 521.

Samuel, E. (1950). Brit. J. Radiol., 23. 157.

Schafer. E. A. Sharpey- (1949). Essentials of Histology. 15th ed. Édited by Carleton, H. M. and Leach, E. H. London.

\section{Addendum}

During the preparation of this paper a further three children suffering from the same condition were seen. Two were bilaterally affected and both of these harboured $x$-haemolytic streptococci and pneumococci, while from the other $x$-haemolytic streptococci alone were isolated. One course of local penicillin in all three has resulted in four months' freedom from relapse. 